\title{
IНТЕНСИВНА ТЕРАПІЯ
}

doi: 10.35339/ekm.2019.01.07

УДК 616.12-008-056.257-001-031.14-083.98

\section{В.В. Кучерявченко, Ю.В. Волкова, К.Ю. Шарлай \\ Харківський національний медичний університет \\ ФУНКЦІОНАЛЬНИЙ СТАН ФЕРМЕНТАТИВНОЇ АКТИВНОСТІ Й КАРДІОСПЕЦИФІЧНИХ МАРКЕРІВ ПРИ ТРАВМАТИЧНІЙ ХВОРОБІ У ПАЦІЄНТІВ З ПІДВИЩЕНИМ ІНДЕКСОМ МАСИ ТІЛА}

\begin{abstract}
Метою нашої роботи був аналіз функціонального стану ферментативної активності й кардіоспецифічних маркерів при травматичній хворобі у пацієнтів з підвищеним індексом маси тіла за допомогою системного багатофакторного аналізу. Аналіз математичних моделей стану ферментативної активності й кардіоспецифічних маркерів у всіх групах хворих визначив, що досліджуваний процес носить закономірний характер з періодами нестабільності стану серцево-судинної системи у відповідь на отримані ушкодження тим виразніше, чим більше у пацієнтів індекс маси тіла на момент надходження до стаціонару.

Ключові слова: кардіоспецифічні маркери, травматична хвороба, системний багатофакторний аналіз, підвищений індекс маси тіла, політравма.
\end{abstract}

\section{Вступ}

Відомо, що тканини відповідають на ушкодження запальною реакцією з різноманітними біохімічними зсувами, що змінюють ферментативну активність тканин і середовища, а також впливають на кисневе забезпечення тканин, в тому числі й міокарда [1]. Саме тому, дослідження кардіоспецифічних маркерів, а також ферментів, $є$ невід'ємною частиною у визначенні клініко-патогенетичних аспектів перебігу травматичної хвороби (ТХ) у хворих 3 підвищеним індексом маси тіла (ПІМТ) [2-3].

При вивченні динаміки кардіальних міоглобінів - тропонінів Т і I, діагностичну цінність тропоніну Т визначають при оцінці величини ішемії міокарда. Відомо, що його піковий рівень обернено пропорційний індексу рухливості стінки, фракції викиду лівого шлуночка, що вимірюється за допомогою двомірної ехокардіографії і контрастної вентрикулографії [4-5].

Найбільш часто вміст тропоніну Т підвищується у хворих зі змінами кінцевої частини шлункового комплексу на ЕКГ, які $є$ передвісниками несприятливого результату у хворих з нестабільною стенокардією [6-7]. Саме тому, вивчення динаміки показників кардіоспецифічних маркерів у хворих з ПІМТ на фоні політравми та їх вплив на тяжкість перебігу ТХ $є$ актуальним, що зумовлює подальші дослідження у цьому напрямку.

Метою нашої роботи був аналіз функціонального стану ферментативної активності й кардіоспецифічних маркерів при травматичній хворобі у пацієнтів $з$ підвищеним індексом маси тіла.

\section{Матеріал і методи}

За допомогою системного багатофакторного аналізу в результаті вивчення динаміки 5-ти провідних показників функціонального стану ферментативної активності та маркерів ушкодження м'язів і міокарда, що були розраховані на підставі 1344 бланків аналізів у 224 хворих з ПІМТ $з$ політравмою, що характеризували дану функціональну систему у термін від однієї доби до 1 року з моменту отримання ушкоджень, були визначені інтегральні показники (табл. 1) і побудовані математичні моделі стану ферментативної активності й кардіоспецифічних маркерів (рисунок). Порівняльний аналіз цих показників дозволив визначити як наявність загальних закономірностей, так і певні особливості, характерні для даних хворих в залежності від IMT на момент отримання пацієнтами політравми.

(C) В.В. Кучерявченко, Ю.В. Волкова, К.Ю. Шарлай, 2019 
Таблиия 1. Динаміка інтегральних показників (Хві)стану ферментативної активності й кардіоспещифічних маркерів у хворих з ПІМТ з травматичною хворобою

\begin{tabular}{|c|c|c|c|}
\hline Доба & $\begin{array}{l}\text { Інтегральний показник } \\
\text { Хві } \pm \sigma_{\text {ві у хворих групи I }}\end{array}$ &  & 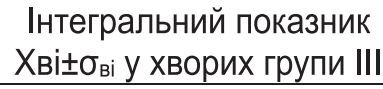 \\
\hline 1-ша & $0,9296 \pm 0,0083$ & $0,7344 \pm 0,0061$ & $0,7162 \pm 0,0029$ \\
\hline 3-тя & $0,7244 \pm 0,0037$ & $0,4292 \pm 0,0048$ & $0,3017 \pm 0,0044$ \\
\hline 7-ма & $0,5182 \pm 0,0071$ & $0,3237 \pm 0,0064$ & $0,3090 \pm 0,0051$ \\
\hline 14-та & $0,3341 \pm 0,0058$ & $0,2723 \pm 0,0081$ & $0,2348 \pm 0,0073$ \\
\hline 30-та & $0,3026 \pm 0,0042$ & $0,1003 \pm 0,0056$ & $0,1026 \pm 0,0041$ \\
\hline 360-та & $0,3118 \pm 0,0031$ & $0,1108 \pm 0,0042$ & $0,0034 \pm 0,0023$ \\
\hline
\end{tabular}

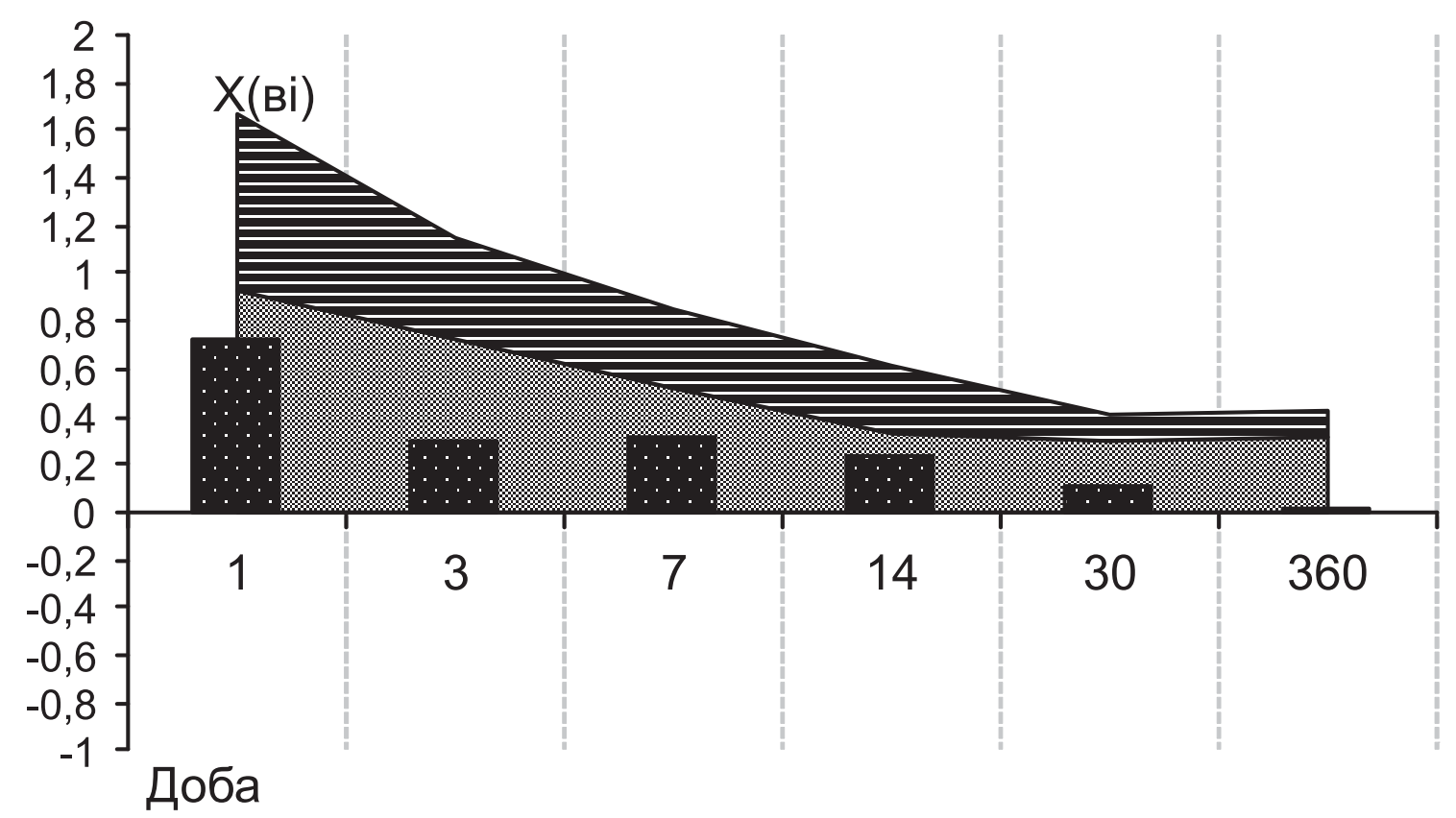

\section{甲 Група I Група II(A) - Група III}

Математична модель функціонального стану ферментативної активності й кардіоспецифічних маркерів при травматичній хворобі у хворих з ПІМТ

\section{Результати та їх обговорення}

Аналіз математичної моделі стану ферментативної активності й кардіоспецифічних маркерів у хворих з ПІМТ з травматичною хворобою визначив певні закономірності змін функціонального стану в різні строки та особливості реагування системи в залежності від IMT пацієнтів кожної із груп (табл. 1, рисунок).

Так поза залежністю від IMT при надходженні інтегральні показники мали позитивні значення з максимальними цифрами за весь період обстеження, Хві =0,9296 $\pm 0,0083$, Хві = $0,7344 \pm 0,0061$ і Хві $=0,7162 \pm 0,0029$ у групах I, II і ІІІ відповідно.

У подальшому була зафіксована однакова динаміка інтегрального показника 3 1-го по 30-й дні перебування у стаціонарі в усіх хворих, при цьому у пацієнтів з IMT 30,0-39,9 кг/м² i
IMT $\geq 40,0$ кг/м² цифри (Хві) були майже ідентичними. На амбулаторному візиті на 360-ту добу спостереження даний показник навпаки різко відрізнявся у групах постраждалих, i, якщо у пацієнтів з IMT $\leq 29,9$ кг/м² він перебував на одному рівні з 14-ї доби протягом цілого року, то у групі III на 360-ту добу спостереження він впав майже до $0, \mathrm{X}_{\text {ві }}=0,0034 \pm$ $\pm 0,0023$, що свідчило про виснаження адаптаційних можливостей функціонування серцевого м'язу і наявність схильності до виникнення ускладнень.

Стосовно вивчення впливу вагових коефіцієнтів на стан ферментативної активності й кардіоспецифічних маркерів у хворих з IMT $\leq 29,9$ кг/м² при політравмі (група I) показники розташувалися так (табл. 2-б): МВ-КФК, ЛДГ-1. Так протягом усього періоду спостереження даних пацієнтів значущими виявили- 
Таблиця 2. Коефіиієнти впливу показника ЛДГ-1 у хворих з ПІМТ з ТХ

\begin{tabular}{|c|c|c|c|}
\hline \multirow[b]{2}{*}{$\begin{array}{c}\text { Доба } \\
\text { обстеження }\end{array}$} & \multicolumn{3}{|c|}{ Групи } \\
\hline & $\begin{array}{c}\text { I } \\
(\text { (IMT до } 29,9 \text { кг/м²) }\end{array}$ & 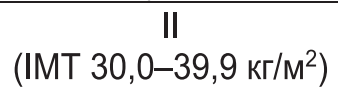 & $\begin{array}{c}\text { III } \\
\left(\mathrm{IMT} \geq 40,0 \mathrm{~K} / \mathrm{M}^{2}\right)\end{array}$ \\
\hline 1-ша & 49,34 & 52,01 & 186,43 \\
\hline 3-тя & 83,16 & 45,11 & 169,26 \\
\hline 7-ма & 29,51 & 70,43 & 221,16 \\
\hline 14-та & 10,26 & 32,54 & 121,93 \\
\hline 30-та & 35,08 & 16,03 & 49,64 \\
\hline 360-та & 30,17 & 41,29 & 28,15 \\
\hline
\end{tabular}

Таблищя 3. Коефіцієнти впливу показника МВ-КФК у хворих з ПІМТ з ТХ

\begin{tabular}{|c|c|c|c|}
\hline \multirow[b]{2}{*}{$\begin{array}{c}\text { Доба } \\
\text { обстеження }\end{array}$} & \multicolumn{3}{|c|}{ Групи } \\
\hline & 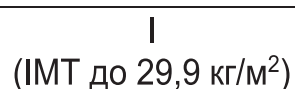 & $\begin{array}{c}\text { II } \\
\left(\text { IMT } 30,0-39,9 \mathrm{kr} / \mathrm{M}^{2}\right)\end{array}$ & $\begin{array}{c}\text { III } \\
\left(\mathrm{IMT} \geq 40,0 \mathrm{k} \Gamma / \mathrm{M}^{2}\right)\end{array}$ \\
\hline 1-ша & 10,29 & 54,08 & 49,43 \\
\hline 3-тя & 81,49 & 88,17 & 96,43 \\
\hline 7-ма & 15,37 & 23,12 & 31,46 \\
\hline 14-та & 21,29 & 21,07 & 18,49 \\
\hline 30-та & 44,12 & 17,06 & 45,02 \\
\hline 360-та & 32,81 & 44,67 & 181,29 \\
\hline
\end{tabular}

Таблиця 4. Коефіцієнти впливу показника тропоніну Т у хворих з ПІМТ з ТХ

\begin{tabular}{|c|c|c|c|}
\hline \multirow[b]{2}{*}{$\begin{array}{c}\text { Доба } \\
\text { обстеження }\end{array}$} & \multicolumn{3}{|c|}{ Групи } \\
\hline & 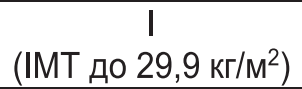 & 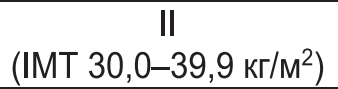 & $\begin{array}{c}\text { III } \\
\left(\mathrm{IMT} \geq 40,0 \mathrm{~K} / \mathrm{M}^{2}\right)\end{array}$ \\
\hline 1-ша & 26,03 & 100,49 & 126,15 \\
\hline 3-тя & 22,49 & 88,43 & 244,03 \\
\hline 7-ма & 18,23 & 45,08 & 178,11 \\
\hline 14-та & 34,71 & 39,22 & 94,21 \\
\hline 30-та & 56,08 & 44,16 & 49,02 \\
\hline 360-та & 54,17 & 200,26 & 256,41 \\
\hline
\end{tabular}

Таблиця 5. Коефіцієнти впливу показника тропоніну I у хворих з ПIМТ з ТХ

\begin{tabular}{|c|c|c|c|}
\hline \multirow[b]{2}{*}{$\begin{array}{c}\text { Доба } \\
\text { обстеження }\end{array}$} & \multicolumn{3}{|c|}{ Групи } \\
\hline & 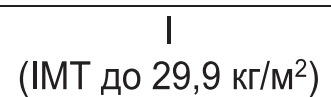 & 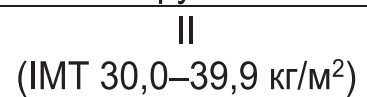 & $\begin{array}{c}\text { III } \\
\left(\mathrm{IMT} \geq 40,0 \mathrm{~K} / \mathrm{M}^{2}\right)\end{array}$ \\
\hline 1-ша & 8,43 & 12,27 & 13,01 \\
\hline 3-тя & 10,26 & 11,08 & 9,43 \\
\hline 7-ма & 7,29 & 10,72 & 18,77 \\
\hline 14-та & 9,13 & 9,74 & 24,26 \\
\hline 30-та & 8,02 & 19,31 & 27,63 \\
\hline 360-та & 7,01 & 8,26 & 10,44 \\
\hline
\end{tabular}

Таблиия 6. Коефіцієнти впливу показника АCT у хворих з ПІМТ з ТX

\begin{tabular}{|c|c|c|c|}
\hline \multirow{2}{*}{$\begin{array}{c}\text { Доба } \\
\text { обстеження }\end{array}$} & \multicolumn{3}{|c|}{ Групи } \\
\hline & 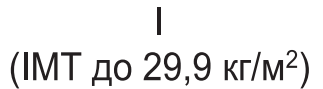 & 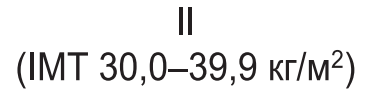 & $\begin{array}{c}\text { III } \\
\left(\mathrm{IMT} \geq 40,0 \mathrm{Kr} / \mathrm{M}^{2}\right)\end{array}$ \\
\hline 1-ша & 20,09 & 48,43 & 61,43 \\
\hline 3-тя & 14,31 & 100,27 & 184,26 \\
\hline 7-ма & 22,17 & 88,34 & 222,07 \\
\hline 14-та & 15,46 & 12,78 & 113,41 \\
\hline 30-та & 19,43 & 26,03 & 44,81 \\
\hline 360-та & 10,27 & 16,41 & 21,04 \\
\hline
\end{tabular}


ся лише цифри ЛДГ-1 $(83,16)$ і МВ-КФК $(81,49)$ на 3 -тю добу перебування у стаціонарі.

У свою чергу, динаміка вагових коефіцієнтів у групі II, IMT 30,0 - 39,9 кг/ м $^{2}$ була дещо більш напруженою - за значущістю показники розташувалися так (табл. 2, 3, 4, 5, 6): тропонін Т, МВ-КФК, АСТ, ЛДГ-1.

Отже, протягом першого тижня після отримання травматичних ушкоджень хворими групи II найбільший вплив на стан ферментативної активності й кардіоспецифічність мав тропонін Т на 1-шу $(100,49), 3$-тю добу $(88,43)$, МВ-КФК на 1 -шу $(54,08)$ і 3-тю $(88,17)$ добу, ЛДГ-1 на 7-му $(70,43)$ і АСТ на 3 -тю $(100,27)$ i 7-му $(88,34)$ добу хвороби.

В подальшому у постраждалих з IMT 30,0 $-39,9$ кг/ $\mathbf{M}^{2}$ важливим визначився лише факт підвищеного вагового коефіцієнта лише у показника тропоніну Т на 360-ту добу спостереження під час амбулаторного візиту і складав $(200,26)$.

У свою чергу, в групі ІІІ за коефіцієнтами досліджувані фактори розподілились таким чином: ЛДГ-1, АСТ, тропонін Т, МВ-КФК. Так, під час раннього періоду ТХ найбільший вплив на клінічну картину перебігу ТХ у пацієнтів 3

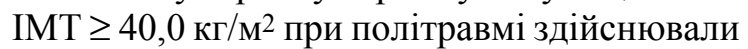
ЛДГ-1 - $(186,43 ; 169,26 ; 221,16 ; 121,93)$ - на 1-шу, 3-тю, 7-му та 14-ту добу відповідно; АCТ - $(184,26 ; 222,07 ; 113,41)$ - на 3-тю, 7-му та 14-ту добу перебування у стаціонарі; тропонін Т - $(126,15 ; 244,03) ; 178,11 ; 94,21)$ на 1-шу, 3-тю, 7-му й 14-ту добу лікування; MBКФК - $(96,43)$ на 3-тю добу проведення інтенсивної терапії. На 30 -ту добу не було виявлено значущого впливу вагових коефіцієнтів. Через рік після отримання пацієнтами групи III політравми значення мали МВ-КФК $(181,29)$ і тропонін Т $(256,41)$.

\section{Висновки}

Під час аналізу математичних моделей стану ферментативної активності й кардіоспецифічних маркерів в усіх групах хворих визначили, що досліджуваний процес носить закономірний характер з періодами нестабільності стану серцево-судинної системи у відповідь на отримані ушкодження і тим вираженіший, чим більше у пацієнтів IMT на момент надходження до стаціонару.

\section{Література}

1. Characteritics and thirty day out comes of emergency department patients with elevated creatinekinase / B. E. Grunau, R. Pourvali, M. O. Wiens, A. Levin, J. Li, E. Grafstein et al. // Acad Emerg Med. - 2014. - № 21 (6). - C. 631-636.

2. Матвеева C. А. Лактатдегидрогеназа и глюкоза крови: особенности взаимосвязей у мужчин с ишемической болезнью сердца и сахарным диабетом 2 типа / С. А. Матвеева, И. В. Матвеева // Евразийский кардиологический журнал. - 2016. - № 2. - С. 102-103.

3. Чернявська I. B. Профіль чинників ризику серцево-судинних захворювань при ішемічній хворобі серця в осіб із нормальним і порушеним вуглеводним обміном / І.В. Чернявська // Міжнародний ендокринологічний журнал. - 2015. - № 8 (72). - С. 83-87.

4. Парахонский А. П. Патогенез клинических проявлений синдрома эндогенной интоксикации / А.П. Парахонский // Заметки ученого. - 2015. - Т. 1. - № 1-1 (1). - С. 188-195.

5. Loss of mitochondrial pyruvate carrier 2 in the liver leads to defects in gluconeogenesis and compensation via pyruvate alanine cycling / K.S McCommis, Z. Chen, X. Fu, W. G McDonald, J. R Colca, R. F Kletzien et al. // CellMetab. - 2015. - № 22. - C. 682-694.

6. Han T. S., Lean M. Ej. A clinical perspective of obesity, metabolic syndrome and cardiovascular disease / T.S. Han, M.Ej. Lean // Cardiovascular Disease. - 2016. - № 5. - P. 1-13.

7. Хрусталёв В. В. Использование активности лактатдегидрогеназы в клинической диагностике / В. В. Хрусталев, А. С. Гончар // Молодой ученый. - 2015. - №7. - С. 40-42. - URL https:// moluch.ru/archive/87/17010/

\section{References}

1. Grunau B.E., Pourvali R., Wiens M.O., Levin A., Li J., Grafstein E., et al. (2014). Characteritics and thirty day out comes of emergency department patients with elevated creatinekinase. Acad Emerg Med., vol. 21 (6), pp. 631-636.

2. Matveeva S.A., Matveeva I.V. (2016). Laktatdegidrogenaza i glyukoza krovi: osobennosti vzaimosvyazey u muzhchin $\mathrm{s}$ ishemicheskoy boleznyu serdtsa i saharnyim diabetom 2 tipa [Lactate dehydrogenase and blood glucose: features of interconnections in men with coronary heart disease and type 2 diabetes]. Yevraziyskiy kardiologicheskiy zhurnal - Eurasian heart journal, vol. 2, pp. 102-103 [in Russian]. 
3. Chernyavska I.V. (2015). Profil chynnykiv ryzyku sertsevo-sudynnykh zakhvoryuvan pry ishemichniy khvorobi sertsya v osib iz normalnym i porushenym vuhlevodnym obminom [A profile of risk factors for cardiovascular diseases in coronary heart disease in individuals with normal and abnormal carbohydrate metabolism]. Mizhnarodnyy endokrynolohichnyy zhurnal - International Endocrinology Journal. vol. 8 (72), pp. 83-87 [in Ukrainian].

4. Parahonskiy A.P. (2015). Patogenez klinicheskih proyavleniy sindroma endogennoy intoksikatsii [Pathogenesis of clinical manifestations of endogenous intoxication syndrome]. Zametki uchenogo Scientist notes, vol. 1, № 1-1 (1), pp. 188-195 [in Russian].

5. McCommis K. S., Chen Z., Fu X., McDonald W.G., Colca J.R., Kletzien R.F et al. (2015). Loss of mitochondrial pyruvate carrier 2 in the liver leads to defects in gluconeogenesis and compensation via pyruvate alanine cycling. CellMetab., vol. 22, pp. 682-694.

6. Han T.S., Lean M.Ej. (2016). A clinical perspective of obesity, metabolic syndrome and cardiovascular disease. Cardiovascular Disease, vol. 5, pp. 1-13.

7. HrustalYov V.V. (2015). Ispolzovanie aktivnosti laktatdegidrogenazyi v klinicheskoy diagnostike [Use of lactate dehydrogenase activity in clinical diagnosis]. Molodoy uchenyiy - Young scientist, vol. 7, pp. 40-42. URL https://moluch.ru/archive/87/17010/.

\section{В.В. Кучерявченко, Ю.В. Волкова, Е.Ю. Шарлай ФУНКЦИОНАЛЬНОЕ СОСТОЯНИЕ ФЕРМЕНТАТИВНОЙ АКТИВНОСТИ И КАРДИОСПЕЦИФИЧЕСКИХ МАРКЕРОВ ПРИ ТРАВМАТИЧЕСКОЙ БОЛЕЗНИ У ПАЦИЕНТОВ С ПОВЫШЕННЫМ ИНДЕКСОМ МАССЫ ТЕЛА}

Целью нашей работы был анализ функционального состояния ферментативной активности и кардиоспецифических маркеров при травматической болезни у пациентов с повышенным индексом массы тела с помощью системного многофакторного анализа. Анализ математических моделей состояния ферментативной активности и кардиоспецифических маркеров во всех группах больных определил, что исследуемый процесс носит закономерный характер с периодами нестабильности состояния сердечно-сосудистой системы в ответ на полученные повреждения тем отчетливее, чем больше у пациентов индекс массы тела на момент поступления в стационар.

Ключевые слова: кардиоспецифические маркеры, травматическая болезнь, системный многофакторный анализ, повышенный индекс массы тела, политравма.

\section{V.V. Kucheryavchenko, Yu.V. Volkova, K.Yu. Sharlai \\ FUNCTIONAL CONDITION OF ENZYMATIVE ACTIVITY AND CARDIOSPECIFIC MARKERS \\ IN TRAUMATIC DISEASE IN PATIENTS WITH IMPROVED BODY MASS INDEX}

The purpose of our work was to analyze the functional state of enzyme activity and cardiospecific markers in traumatic disease in patients with an increased body mass index using systemic multivariate analysis. Analysis of mathematical models of the state of enzymatic activity and cardiospecific markers in all groups of patients determined that the process under study is regular with periods of instability of the state of the cardiovascular system in response to the injuries received the more clearly the greater the patient's body mass index at the time of admission to the hospital.

Keywords: cardiospecific markers, traumatic disease, systemic multivariate analysis, increased body mass index, polytrauma.

Надійшла до редакиії 08.02.2019

\section{Контактна інформація}

Кучерявченко Валерій Вікторович - кандидат медичних наук, асистент кафедри медицини невідкладних станів, анестезіології та інтенсивної терапії Харківського національного медичного університету.

Адреса: Україна, 61022, м. Харків, просп. Науки, 4.

Тел.: +380951502947.

E-mail:vvk@ukr.net.

ORCID: 0000-0001-9360-8258. 
Волкова Юлія Вікторівна - доктор медичних наук, завідувач кафедри медицини невідкладних станів, анестезіології та інтенсивної терапії Харківського національного медичного університету.

Адреса: Україна, 61022, м. Харків, просп. Науки, 4.

Тел.: +380953196463.

E-mail:dryu.volkova@gmail.com.

ORCID: 0000-0002-6248-3576.

Шарлай Катерина Юріївна - кандидат медичних наук, асистент кафедри медицини невідкладних станів, анестезіології та інтенсивної терапії Харківського національного медичного університету.

Адреса: Україна, 61022, м. Харків, просп. Науки, 4.

Тел.: +380638541962.

E-mail: sharlaik@gmail.com.

ORCID: 0000-0002-1930-8289. 